\title{
Biofungicide Producing Bacteria: an In Vitro Inhibitor of Ganoderma boninense
}

\author{
Ade Irma ${ }^{1}$, Anja Meryandini2 ${ }^{*}$, Bedah Rupaedah ${ }^{3}$ \\ 'Study Program of Microbiology, Department of Biology, Faculty of Mathematics and Natural Sciences, Bogor Agricultural University, \\ Bogor, Indonesia \\ ${ }^{2}$ Department of Biology, Faculty of Mathematics and Natural Sciences, Bogor Agricultural University, Bogor, Indonesia \\ ${ }^{3}$ Agency for Assessment and Application of Technology, Biotechnology Center, Serpong, South Tangerang, Indonesia
}

\section{ARTICLE INFO}

\section{Article history:}

Received August 23, 2017

Received in revised form November 21, 2017

Accepted January 5, 2018

\section{KEYWORDS:}

Antifungal,

endophytic bacteria,

antagonistic effect,

G.boninense

\begin{abstract}
Oil palm is widely known as one of vegetable oil sources and the main comodity in Indonesian agriculture because of the benefits in non-food and food industries. Ganoderma boninense attack results in considerable losses to agriculture. Chemical control creates a harmful effect on health and the environment. Biocontrol is required to take over the function of chemical control. This study aimed to select bacteria that produce bioactive compounds as biofungicide against $G$. boninense pathogenic fungi and identify bacteria producing biofungicide using molecular method. The stages of bacterial isolate selection were performed through the selected hemolysis and isolate tests in the antagonistic test. Bacteria were extracted using ethyl acetate and their extract activity were tested. Analysis of bioactive compounds was conducted using thin layer chromatography (TLC) and the identification was based on $16 \mathrm{~S}$ rRNA gene. The result of bacterial pathogenic test was obtained from two selected bacterial isolates namely $11 \mathrm{~B}$ LB and 11B MD. Both bacterial isolates showed antagonistic effects by forming an inhibitory zone against $G$. boninense growth with percentage of inhibitor of 81 and $75 \%$. Activity test of bacterial extract showed that crude extract of bacterial isolate 11B MD had the highest inhibitor activity that is $\mathbf{8 8 . 3 4 \%}$. TLC analysis proved that the active extract of bacteria containing metabolite compounds had $R$ f value of $0.1,0.28$, and 0.38. Isolate bacteria 11B MD was identified as Pseudomonas aeruginosa.
\end{abstract}

\section{Introduction}

Oil palm (Elaeis guineensis Jacq.) is one of the vegetable oil sources that become the main commodity in agriculture in Indonesia. Production of palm oil is used in the food industries and chemicals. It also substitutes fuel oil which is currently mostly preferred for petroleum. Based on data from Food Agriculture Organization (FAO), Indonesia has the highest average area of oil palm plantation in 20082012 which amounted to $35.69 \%$ of the total area of oil palm plantation in the world. Malaysia ranks second for oil palm plantations and followed by Nigeria while Thailand ranks fourth (Indarti et al. 2014).

Productivity data for oil palm crops in 2008-2012 provided information on significant differences between oil palm plantation area and productivity

\footnotetext{
* Corresponding Author

E-mail Address: ameryandini@yahoo.com
}

values, particularly in Indonesia and Thailand. Indonesia occupies the last position in terms of productivity compare to Thailand which has a productivity value of about 17.2 tons/ha (Indarti et al. 2014). The low value of palm oil productivity in Indonesia is caused by several factors and one of them is the attack of pathogenic microorganisms. One of the pathogens concerned in attacking oil palm crops is Ganoderma boninense which can cause basal stem rot (BSR) (Naher et al. 2012). Susanto et al. (2005) stated that basal stem rot disease known as BSR disease can affect oil palm production because it causes death up to $50 \%$. In addition, BSR disease results in producing fewer fruits of palm oil plants or even do not produce any fruit at all, thereby this disease results in decreasing palm oil production.

Synthetic fungicides are used by farmers as attempts to suppress pathogen attacks. The use of synthetic fungicides can accelerate the occurrence of pathogenic races so that they are resistant. In addition, 
it can cause poison to humans and the residue can cause environmental pollution (Hadizadeh et al. 2009). Biocontrol is an effective alternative in controlling losses due to pathogenic fungi so as to reduce the impact of plant disease attack. The microorganisms that have the potential to be used as biocontrol agents against $G$. boninense attack are bacteria. Bacteria have a faster and more adaptable growth in less favorable environments. Pseudomonas alcaligenes, Bacillus pumilus and Rhizobium sp. can be used as biocontrol because it produces antifungal compounds that inhibit pathogenic fungi (Akhtar et al. 2010). Asaka and Shoda (1996) confirmed that several Bacillus strains has a variety of antifungal compounds such as cyclic lipopeptides which is effectively used as a biocontol agent to overcome pathogens on plants.

The use of biocontrol agents that play a role in inhibiting the attack of $G$. boninense pathogenic fungal has not showed a significant effectiveness. Information on organisms that are potentially used as biocontrol agents is needed. Previous research results have obtained bacterial isolates from healthy oil palm plants in Lebak and Medan that are believed to have a role in resisting and inhibiting the growth of $G$. boninense. Identification of bacteria and analysis of metabolite compounds that have the ability as a biofungisida against pathogenic fungi have not been analyzed in this study using the bacteria isolates.

\section{Materials and Methods}

\subsection{Selection of Bacterial Isolates through Hemolysis Test}

Five bacterial isolates (P10 LB, 11B LB, 1TSA LB, 11B MD, and 1TSA MD) from the collection of Agromicrobiology Laboratory in Agency for Assessment and Application of Technology, South Tangerang were selected by hemolysis test. The five bacterial isolates were scratched on the blood agar medium and incubated at $37^{\circ} \mathrm{C}$ for 24 hours. Selection was performed on the pathogenity of the five bacterial isolates characterized by the formation of the hemolytic zone.

\subsection{Bacterial Isolate Antagonistic Test Against Ganoderma boninense}

The bacterial antagonistic test against $G$. boninense was performed on the basis of Bivi et al. (2010) that is double culture method (dual culture). G. boninense cultures were taken about $1 \mathrm{~cm}$ and placed on Potato Dextrose Agar (PDA) medium. Bacterial isolates tested were scratched in contrast to the fungus. Positive control was performed using nystatin (commercial antifungal). Subsequently incubation was performed for 7 to 14 days at room temperature, and observed the antagonistic effect of bacterial isolate on growth of mycelium fungus $G$. boninense. Inhibitory activity was known by measuring the growth of mycelium fungus and see whether or not the inhibition zone was formed. The inhibitory level was calculated using the formula $\mathrm{IP}=\mathrm{R} 1-\mathrm{R} 2 / \mathrm{R} 1 \times 100 \%$, where IP = inhibition percentage, $\mathrm{R} 1$ = growth of pathogen in control, and $\mathrm{R} 2$ = growth of pathogens on dual culture treatment.

\subsection{Measurement of Growing Bacterial Curve}

Stages of measurement of bacterial growth began with bacterial preculture. The result of bacterial preculture was reoccupied on Nutrient Broth (NB) medium and incubated on a shake machine with $150 \mathrm{rpm}$ agitation. Measurement of bacterial growth was done every 4 hours for 24 hours. Total plate count (TPC) method is used in the measurement of bacterial growth. A total of $1 \mathrm{ml}$ of bacterial culture was inserted into a test tube containing $9 \mathrm{ml}$ of $0.85 \% \mathrm{NaCl}$ physiologic solution. Serial dilution was made from $10^{-1}$ up to $10^{-8}$. The $10^{-5}$ to $10^{-8}$ dilution series were taken as much as $0.1 \mathrm{ml}$ to be inserted into a petri dish containing Nutrient Agar (NA). It was trimmed and incubated at room temperature were done.

\subsection{Extraction of Bacteria Producing Antifungus Compounds}

Bacterial isolates were grown on NB media and harvested as bacterial cells begun in the logarithmic growth phase until death phase. The bacterial cells obtained were centrifuged at $10.000 \mathrm{rpm}$ for 10 minutes. The supernatant portion was added solvent ethyl acetate with a ratio of $1: 1(\mathrm{v} / \mathrm{v})$. The mixture was inserted into a separating funnel and shaken for 15 minutes. The formed organic solvent was concentrated using a rotary vacuum evaporator at a temperature of $\pm 40^{\circ} \mathrm{C}$ (Abdel-Raouf and Ibraheem 2008).

\subsection{Activity Test of Extracted Bacterial Culture on Ganoderma boninense}

This test used modificated cylinder-plate method (Cui et al. 2012) that is by making wells on PDA media using cork borrer. Supernatant extracts from bacterial cultures were fed into a well with a concentration of $10.000 \mathrm{ppm}$. Next, about $1 \mathrm{~cm}$ of fungus $\mathrm{G}$. boninense was placed on PDA media beside the wells containing extracts. As a positive control, nystatin was used in the same concentration with those on the extract. Negative control was performed with no addition of extract. Measurement of inhibition rate of bacterial extract was done according to method Bivi et al. (2010). 


\subsection{Thin Layer Chromatography (TLC)}

The TLC plate used was silica gel $\mathrm{GF}_{254}$ while the eluent used was the ratio of ethyl acetate and n-hexane concentration. Bottling of bacterial extract on TLC plate was done using capillary pipe. The elution process was performed by placing the TLC plate vertically on the chamber wall containing the eluent. The TLC plates were removed from the chamber to be observed staining spots formed under UV light $\lambda 254$ and $\lambda 366 \mathrm{~nm}$. The calculation of Rf values corresponds to Wagner et al. (1984).

$$
R f=\frac{\text { Range of component }}{\text { Range of eluent }}
$$

\subsection{Identification using Molecular Method}

Bacterial DNA was isolated using the Cetyl Trimethylammonium Bromide (CTAB) method (Ausubel et al. 1997). DNA amplification was done using universal primer namely primer forward 27F and 1492R(Frank et al. 2008). The amplification process occured on a Polymerase Chain Reaction (PCR) machine with composition and PCR reaction conditions were based on a procedure performed by Zarei et al. (2012). The PCR reaction composition was $15 \mu \mathrm{l} \mathrm{PCR} \mathrm{Master} \mathrm{Mix} \mathrm{(i} \mathrm{TaqTM)} \mathrm{2X,}$ $3 \mu$ DNA template, $3 \mu$ l for primary forward, $3 \mu$ l reverse primer, and $6 \mu$ nuclease free water $\left(\mathrm{dd}_{2} \mathrm{O}\right)$. The PCR conditions used were predenaturation $\left(94^{\circ} \mathrm{C}, 5 \mathrm{~min}\right)$, 35 cycles of denaturation $\left(94^{\circ} \mathrm{C}, 0.5 \mathrm{~min}\right)$, annealing $\left(55^{\circ} \mathrm{C}, 0.5 \mathrm{~min}\right)$, extension $\left(72^{\circ} \mathrm{C}, 1.5 \mathrm{~min}\right)$, and post extension $\left(72^{\circ} \mathrm{C}, 5 \mathrm{~min}\right)$. The result of amplification (amplicon) was assesed by electrophoresis on $1 \%$ agarose gel and the result of 16S rRNA amplicon is purified and sequenced. The results of sequencing were then aligned with the Gene Bank data. The process was carried out on database of National Center for Biotechnology Information website (http://www.ncbi. nlm.nih.gov) using BLASTN (Basic Local Alignment Search Tool-Nucleotida) to identify bacterial isolates.

\section{Results}

\subsection{Selection of Bacterial Isolates Through Hemolysis Test}

The bacterial isolates used in this study were selected based on the presence or absence of pathogens possessed by the five unidentified bacterial isolates: P10 LB, 11B LB, 1TSA LB, 11B MD, and 1TSA MD. The results show that there were 3 bacterial isolates that had the ability to lyse blood cells (pathogenic). The pathogenicity of bacteria was measured from the formation of hemolytic zones around the bacterial colonies that grew on the gel agar medium after incubation for 1 x 24 hours. Two other bacterial isolates, 11B LB and 11B MD showed no activity in lysing blood cells (Figure 1). Both bacterial isolates were used in subsequent tests.

\subsection{Antagonistic Test of Bacterial Isolate Against Ganoderma boninense}

The results of antagonistic test showed that bacteria isolates 11B LB and 11B MD had effective capability in inhibiting growth of $G$. boninense i.e. $81 \%$ and $75 \%$ respectively. The positive control used was nystatin dissolved in dimethyl sulfoxide (DMSO) or methanol solvent which showed the percentage of inhibition rate of 83 and 78\% (Table 1). In addition, there was an inhibition zone formed by bacterial isolates (Figure 2 ) which proved the two selected bacterial isolates had the ability to inhibit the growth of $G$. boninense.

\subsection{Measurement of Growing Bacterial Curve}

The result indicated that bacterial isolates had a short adaptation phase so that the growth can directly enter the logarithmic phase (exponential phase). Both isolates were long enough in logarithmic phase, which presented from hours 0 to 16 . In this phase, the bacterial cells in isolate 11B LB continued to increase in number from $1.5 \times 107 \mathrm{CFU} / \mathrm{ml}$ to $2.8 \times 10^{9} \mathrm{CFU} /$ $\mathrm{ml}$. Bacterial cells in isolate $11 \mathrm{~B} \mathrm{MD}$ cells at the $0^{\text {th }}$ hour was $2.1 \times 10^{7} \mathrm{CFU} / \mathrm{ml}$ and it increased at $16^{\text {th }}$ hour to $3.4 \times 10^{9} \mathrm{CFU} / \mathrm{ml}$. Stationary phase started after logarithmic phase. Stationary phase in both bacterial isolates was quite short and led to the phase of death. The death phase of both bacterial isolates

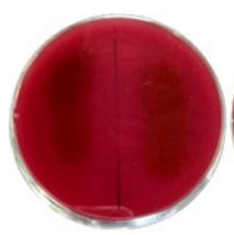

a

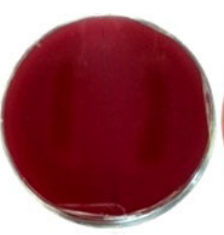

b

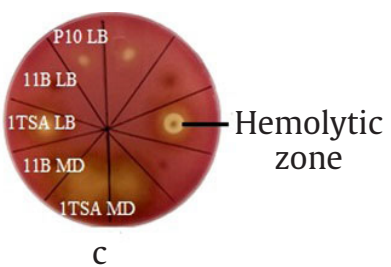

Figure 1. The result of hemolysis test of bacterial isolates on the blood agar media. (a) isolate 11B LB, (b) isolate $11 \mathrm{~B} \mathrm{MD}$, and (c) the five bacterial isolates

Table 1. The percentage of inhibition of bacterial isolates against the growth Ganoderma boninense (\%)

\begin{tabular}{lc}
\hline Isolate & $\begin{array}{c}\text { Percentage of } \\
\text { inhibition (\%) }\end{array}$ \\
\hline Negative control (G. boninense) & 0 \\
11B LB (Lebak) & 81 \\
11 B MD (Medan) & 75 \\
Positive control (nystatin was & 83 \\
dissolved into DMSO) & 78 \\
Positive control (nystatin was & \\
dissolved into methanol) &
\end{tabular}


11B LB and 11B MD occurred until the $24^{\text {th }}$ hour. It was characterized by a decrease in the number of bacterial cells. Bacterial isolate 11B LB decreased in number of cells up to 24 hours with a value of $2.5 \times 10^{9} \mathrm{CFU} / \mathrm{ml}$. Bacterial isolate $11 \mathrm{~B} \mathrm{MD}$ was $2.5 \times 10^{9} \mathrm{CFU} / \mathrm{ml}$ (Figure 3 ). This bacterial growth phase became a reference in determining suitable time in harvesting bacterial cells for the extraction process that is at $8^{\text {th }}$ to $24^{\text {th }}$ hour.

\subsection{Activity Test of Extracted Bacterial Culture on Ganoderma boninense}

The crude extract of viscous fluid was obtained from the supernatant extraction of bacterial culture in logarithmic growth phase to death phase. Extracted bacterial culture at the $8^{\text {th }}, 12^{\text {th }}, 16^{\text {th }}, 20^{\text {th }}$, and $24^{\text {th }}$ hour were tested to see their activity on $G$. boninense. The results of activity test explained that only crude extracts from bacterial culture $11 \mathrm{~B}$ MD at $8^{\text {th }}$ and $24^{\text {th }}$ hour had inhibitory activity. The inhibition values were 86.67 and $88.34 \%$ (Table 2 ) respectively. Treatment of crude extract of bacterial isolate 11B LB did not show

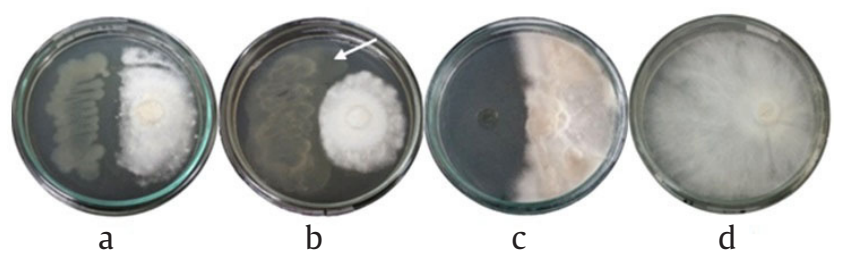

Figure 2. The effect of inhibition of bacterial isolates against of $G$. boninense with incubation time for 14 days at room temperature. (a) isolate bacteria $11 \mathrm{~B} \mathrm{LB},(\mathrm{b})$ isolate $11 \mathrm{~B} \mathrm{MD}$, (c) nystatin (positive control), and (d) growth of G. boninense (negative control)

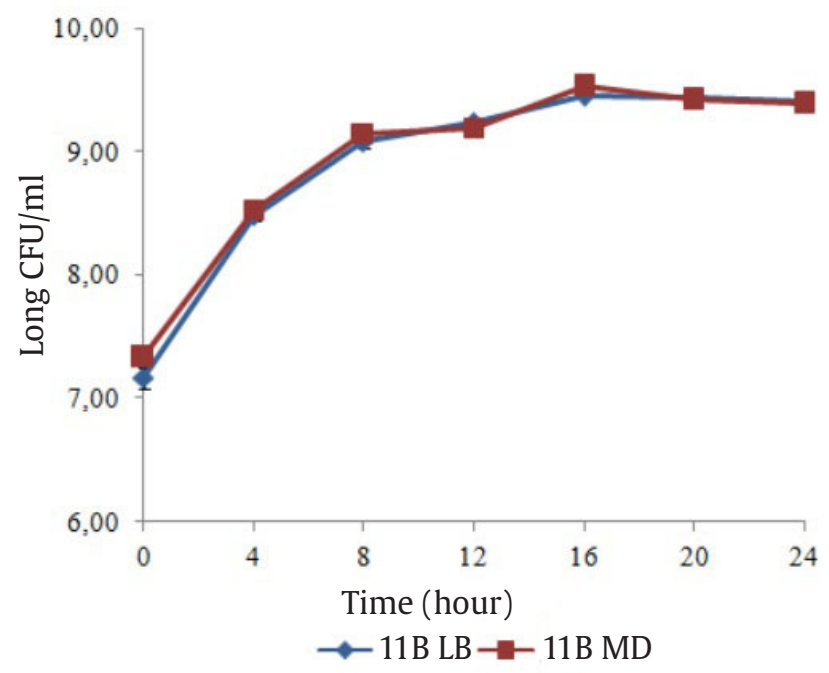

Figure 3. The growth curve of bacterial isolates of 11B LB and $11 \mathrm{~B} \mathrm{MD}$ any inhibition on growth of mycelium $\mathrm{G}$. boninense. A positive control using nystatin showed an inhibition with a value of $60 \%$ while in the negative control there was no inhibitory activity (Figure 4 ).

\subsection{Thin Layer Chromatography (TLC)}

Extract of supernatant bacterial culture at the $8^{\text {th }}$ and $24^{\text {th }}$ hour indicated the presence of inhibition. The compound content was analyzed by TLC method.

Table 2. The inhibition percentage of bacterial supernatant extract in inhibiting the growth of $G$. boninense (\%)

Bacterial crude extract Percentage of inhibition (\%)

Negative control (without 0

treatment)

Positive control (nystatin 60

was dissolved in methanol)

11 B MD (Medan) from the $\quad 86.67$

culture $8^{\text {th }}$ hour

11B MD (Medan) from the $\quad 88.34$

culture $24^{\text {th }}$ hour

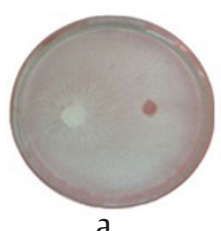

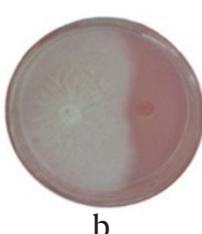

b

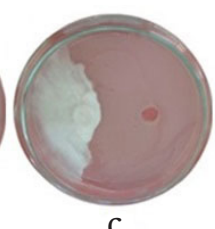

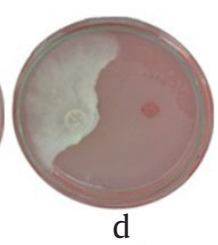

d
Figure 4. Effect of bacterial supernatant extract of isolate 11B MD on the growth of G. boninense with incubation time for 14 days at room temperature. (a) without crude extract (negative control), (b) nystatin (positive control), (c) supernatant extract of bacterial culture 11B MD at $8^{\text {th }}$ hour, and (d) at $24^{\text {th }}$ hour
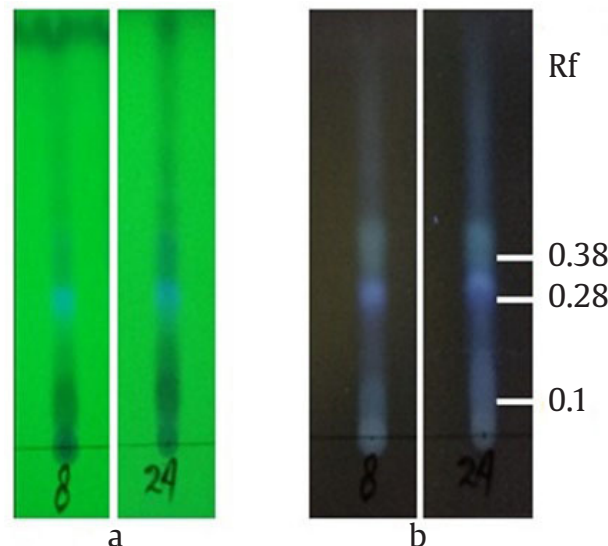

Figure 5. Result of TLC of bacterial crude extract of isolate 11B MD from culture at $8^{\text {th }}$ and $24^{\text {th }}$ hour. (a) observation under $254 \mathrm{~nm}$ UV light and (b) $366 \mathrm{~nm}$ UV lamp 


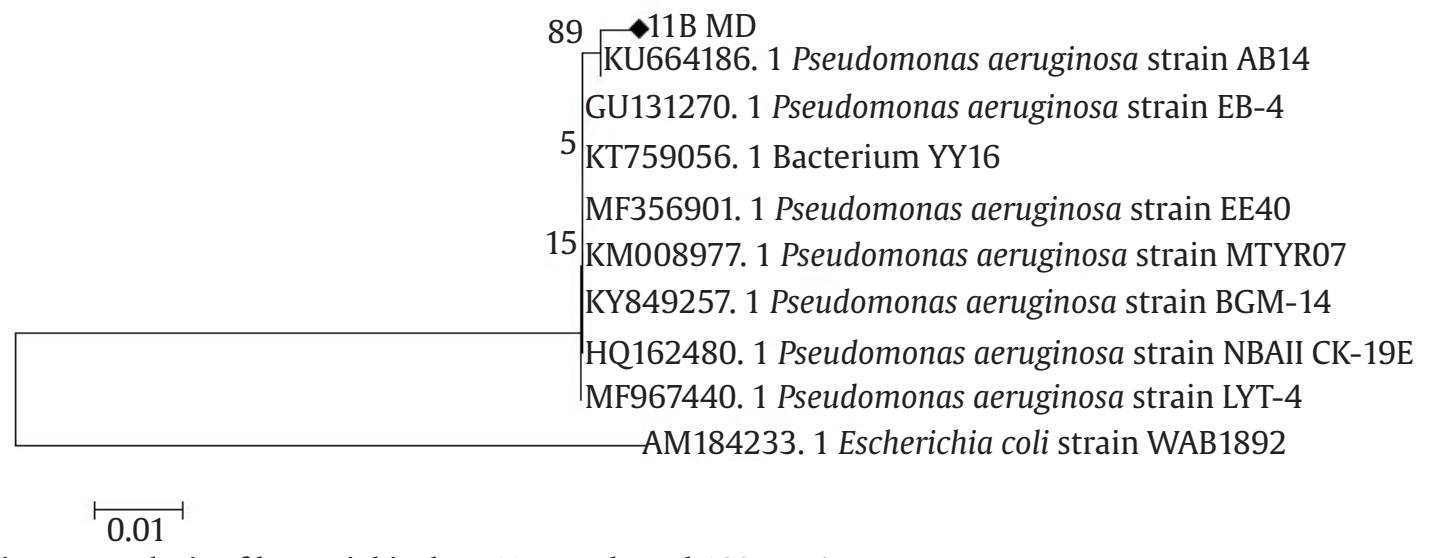

Figure 6. Phylogenetic tree analysis of bacterial isolate 11B MD based 16S rRNA gene

Distribution of the top 149 Blast Hits on 100 subject sequences

Mouse over to see the title, click to show alignment

Color key for alignment scores

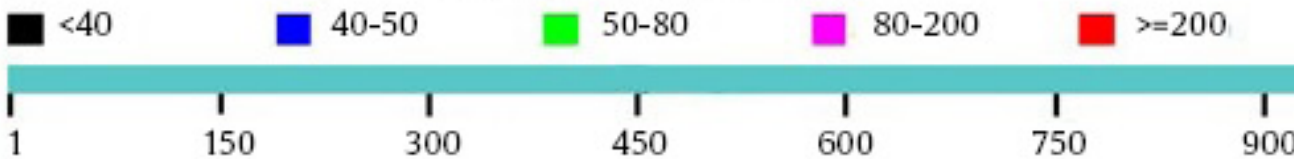

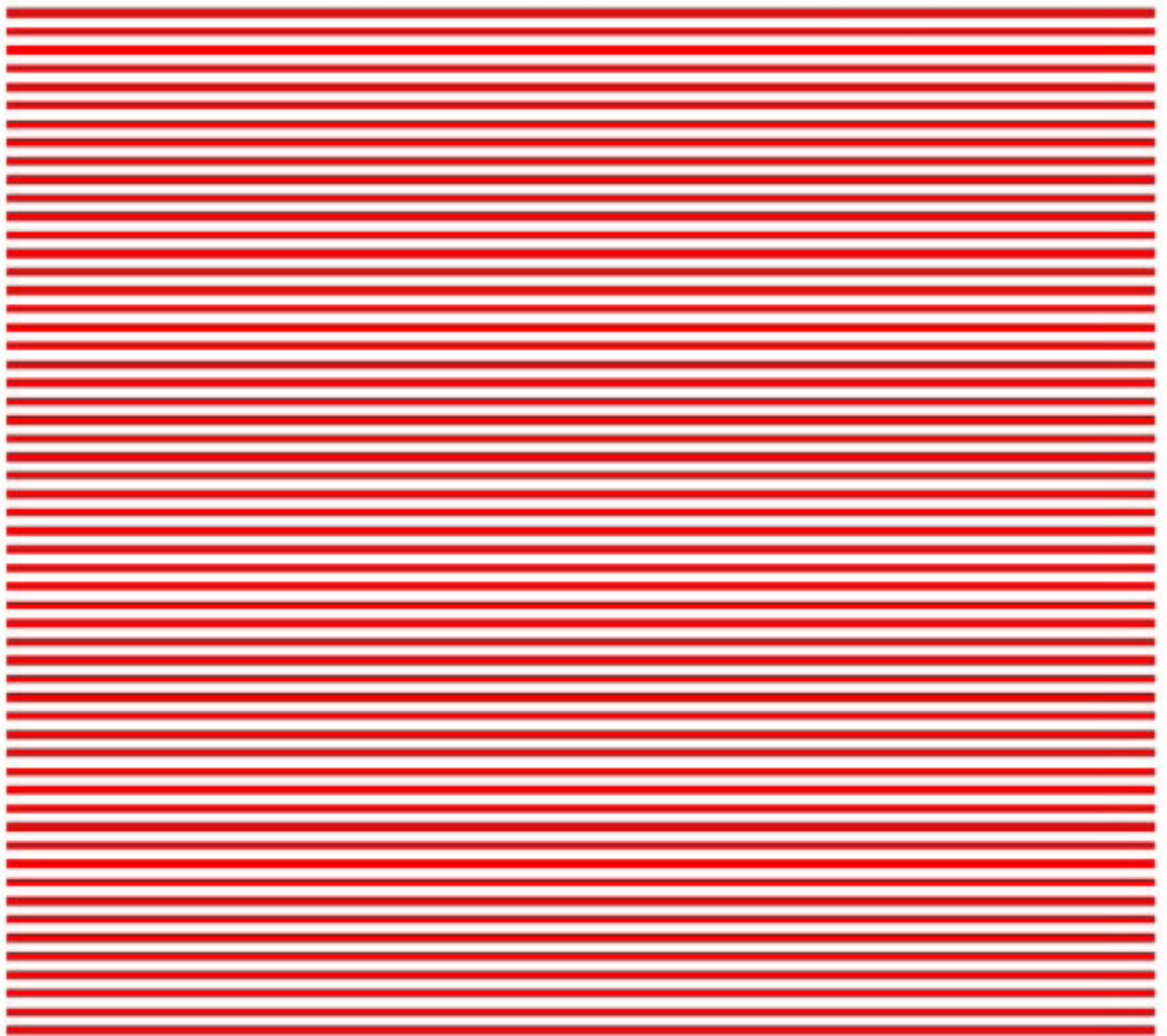

Figure 7. Result of BLAST-N sequence of $16 \mathrm{~S}$ rRNA gene with the Gene Bank data isolate 11B MD 
Chromatographic analysis proved the presence of metabolite compounds that contained bacterial supernatant extract but had not been identified. The compounds contained in the bacterial extracts were separated in the 3:1 eluent ratio (ethyl acetate: n-hexane). The results observed from the stains found on the chromatogram. In addition, stains and $\mathrm{Rf}$ values of supernatant extracts from bacterial cultures at $8^{\text {th }}$ and $24^{\text {th }}$ hours showed similarity. The retention factor (Rf) value of the stain was $0.1,0.28$, and 0.38 (Figure 5).

\subsection{Identification using Molecular Method}

The analysis of metabolite compounds proved that bacteria isolate $11 \mathrm{~B}$ MD has several bioactive compounds and subsequently performed molecular identification of the isolates. Molecular identification using $16 \mathrm{~S}$ rRNA gene was aimed to identify the species name of bacteria isolate $11 \mathrm{~B} \mathrm{MD}$. PCR results from sequences of 16S rRNA after assembling at BLAST showed that the bacterial isolates were believed to be Pseudomonas aeruginosa with $99 \%$ of similarity (Figure 6).

\section{Discussion}

Knowing the stages of bacterial isolate selection was aimed to select potential bacterial isolates which serve better biocontrol agents. Selected bacterial isolates did not form clear zones or hemolytic zones on blood agar media. This means that it is not pathogenic. Pathogenic bacteria are capable of producing hemolisin which causes disease for humans (Figueroa-Lopez et al. 2016). Pathogenic bacteria are able to produce hemolisin that lyses blood cells as components on the agar media. Blood agar media is a differential medium used to distinguish the type of hemolytic in bacteria. Pathogenic bacterial isolates show different hemolytic types. Bacterial isolate P10 LB and ITSA LB showed this by forming a clear zone around the bacterial colony. However, bacterial isolates ITSA MD formed greenish color on blood agar media. This fact is in line with what McKane and Kandel (1998) said that bacteria with $\beta$-hemolysis capabilities will be able to lyse blood cells perfectly characterized by clear zones around the growing bacterial colonies. Bacteria that have a type of $\alpha$-hemolysis can not lyse the blood cells perfectly marked by the change of media color to greenish.

Antagonistic test showed that selected bacterial isolates had inhibitory activity against Ganoderma boninense growth. Inhibition value of bacterial isolates proves that both selected bacterial isolates have the ability to inhibit $G$. boninense growth in vitro. This is in accordance with Bivi et al. (2010) that endophytic bacteria isolated from oil palm plants has inhibition value greater than $50 \%$ against $G$. boninense. Ramli et al. (2016) confirmed that Pseudomonas aeruginosa isolated from oil palm plants has inhibitory activity against G. boninense valued at 70\%. Inhibitory capability is due to the metabolism produced by both bacterial isolates such as bioactive compounds that can inhibit the growth of $G$. boninense. Macroscopic observation showed that bacterial isolate 11B MD was able to produce inhibition zone against $G$. boninense. Inhibition zone is a form of resistance performed by bacteria so that there is no direct contact between bacterial cells with fungal cells. Formed zone of inhibition on bacterial isolates is influenced by competition in nutrition as well as environmental factors (Nawangsih et al. 2010).

The presence of phases that occur during bacterial growth was presented by bacterial growth curve. The growth curve showed that both isolates 11B LB and 11B MD had a short adaptation phase. The condition is caused due prior to observing the growth curve performed before preculture that accelerate the growth of bacteria for leading logarithmic phase. Schultz and Kishony (2013) explained that the phase lag/adaptation of bacterial growth is influenced by the new environmental conditions and the amount of inoculum. The duration of logarithmic phase that occurs in both bacterial isolates showed an activity increase in number of bacterial cells up to $16^{\text {th }}$ hour. Bacillus amyloliquefaciens SAHA 12.07 and Serratia marcescens KAHN 15.12 has logarithmic phase up to $6^{\text {th }}$ hour in which this phase primary metabolite was produced in the form of chitinase that capable of lysing the cell walls of fungi that interfere with the growth of G. boninense (Azizah et al. 2015).

The stationary phase experienced by both bacterial isolates started from the $16^{\text {th }}$ hour and it has entered the phase of death at $20^{\text {th }}$ hour. In the stationary phase, secondary metabolite products are produced such as antibiotics or other bioactive compounds that are toxic to microorganisms. Secondary metabolite products can be exploited by bacteria as a form of defense against unfavorable conditions. This is confirmed by Vater et al. (2002) that bacterial growth produce metabolite products in the stationary phase of antifungal compounds that can inhibit the growth of pathogenic fungi. In the phase of death, there was a decrease in the number of cells due to excessive accumulation of toxins and depletion of nutrients so that more bacterial cells were dead.

The extraction was conducted using ethyl acetate as a semipolar solvent had a wide polarity range. The polarity range of the solvent can attract the antifungal 
compounds contained in the supernatant bacterial culture. This is confirmed by Prapagdee et al. (2012) that the use of ethyl acetate solvent can extract the antifungal compounds found in bacterial cultures. The extract activity test showed that the crude extract of supernatant bacterial culture 11B LB was inactively inhibited the growth of mycelium $G$. boninense. The condition is caused by the difference of solubility level in the bacterial metabolite so that not all metabolite compounds can be drawn by semipolar solvent. As a result, at least ther is a metabolite product that can be extracted in a supernatant bacterial culture. Therefore, the extract test showed a low inhibitory activity against $G$. boninense growth.

Extracts that have inhibitory activity against G. boninense are crude extracts from supernatant bacterial culture $11 \mathrm{~B}$ MD at 8 and 24 hours. Other crude extracts (extracts from $12^{\text {th }}, 16^{\text {th }}$, and $20^{\text {th }}$ cycle cultures) have a low inhibitory activity. This is caused by the concentration of metabolite products produced greater at the $8^{\text {th }}$ and $24^{\text {th }}$ hour. Metabolite product that were produced is antifungal because the extract test indicates the presence of inhibitory activity against the growth of the fungus. Factors that affect the growth of bacteria are nutrients contained in the media and environmental conditions of bacterial growth such as temperature, agitation, $\mathrm{pH}$ and so forth. The process of bacterial metabolism is very sensitive to change in bacterial growth factors that can affect the synthesis of metabolites at the time of bacterial growth phase.

Supernatant culture 11B MD extract at $8^{\text {th }}$ hour was from bacterial cultures harvested in the logarithmic growth phase. The $24^{\text {th }}$ hour extract was derived from the culture of death phases. In general, primary metabolites such as enzymes can be produced in the logarithmic phase. On the other hand, it is still possible to produce secondary metabolite products which are commonly forned in stationary phase. PetatanSagahon et al. (2011) explained that the culture of $P$. fluorescens 16 in the logarithmic phase can inhibit the growth of pathogenic fungi in plants. This is confirmed by Zvanych et al. (2014) that said secondary metabolite compounds can be produced in the mid-logarithmic and stationary-phase. Crude extracts from the $24^{\text {th }}$ hour supernatant culture also demonstrated the ability to inhibit $G$. boninense fungi. This is due to the presence of metabolite compounds contained in the extract. Ramachandran et al. (2014) stated that in the mid and final conditions of the stationary phase, bacterial growth is produced secondary metabolites. It explains that the compounds produced by bacteria isolate 11B MD are able to inhibit the growth of $G$. boninense as it is similar to the case with positive control treatment. This result is proved by giving the same concentration between crude extract and nystatin by showing similarity as antifungal. Therefore, compounds of bacterial isolate 11B MD can be used as antifungal because they have inhibiting properties such as nystatin which is a commercial antifungal.

The crude extracts from supernatant bacterial culture showing the presence of inhibitory activity were then analyzed using thin layer chromatography (TLC). This method is performed to determine the metabolite compounds contained in an extract. In the chromatogram seen a stain formed when observed under UV light. The presence of a fluorescent stain indicates the presence of a compound having a chromophore group. The chromophore group may interact with UV light to form a stain on the chromatogram and the chromophore has a conjugated double bond. Laniado-Laborin and Cabrales-Vargas (2009) stated that antifungal compounds with conjugated double bonds may disrupt the permeability of the fungal cell membranes resulting in damage. This damage inhibit the growth of the fungus as a consequence of the incapability of transport process, selective, and protection of the cell membranes.

Fluorescent stains under UV light prove the presence of certain compounds that can absorb UV light at wavelengths of 254 and $366 \mathrm{~nm}$. Gupta et al. (2012) explained that TLC results from bacterial extracts containing metabolite compounds may glow after being observed in UV light 254 and $366 \mathrm{~nm}$. Rf values showed that the compounds contained an extract. The Rf values obtained (Figure 5) are consistent with the results of a study conducted by Caldeira et al. (2007) that bioactive antifungal compounds has $\mathrm{Rf}$ value which is equal to $0.22,0.28$, and 0.38 . The result of $\mathrm{Rf}$ value obtained shows that the group of compounds in bacterial extract are suspected to be phenol compounds. Group of phenol compounds proposed by Gomathi et al. (2012) shows Rf value of $0.06,0.13,0.21,0.28,0.36,0.38,0.44,0.73,0.84$, and 0.94 . The statement was also reinforced by Chong et al. (2012) that syringic acid which is a kind of phenol compounds has the ability to inhibit the growth of $G$. boninense causes basal stem rot of oil palm plantation.

Molecular identification of bacterial isolate 11B MD was performed based on the encoding gene of 16S rRNA. The $16 \mathrm{~S}$ sequence of rRNAs has a stable (conservative) base sequence and undergoes very slow evolutionary changes. In addition, it can be used to track the relationship of kinship on each bacteria so it is appropriate to be used in identification (Figure 6). Identification using a gene encoding $16 \mathrm{~S}$ rRNA showed that isolate 11B MD was assumed to be $P$. aeruginosa with a similarity value of $99 \%$. This is reinforced by Drancourt et al. (2000) statement that the data are 
considered as the same species if they have similarity values greater than $99 \%$ based on sequences of $16 \mathrm{~S}$ rRNA gene. Tests conducted has proved that the bacteria $P$. aeruginosa has the ability to inhibit the growth of mycelium G. boninense. Suryadi et al. (2014) explains that $P$. veronii can produce chitinase enzymes and in $P$. aeruginosa bacteria can produce glucanase. Therefore, they potentially are biocontrol agents to reduce pathogenic fungi in plants. Both enzymes are enzymes that can degrade the cell wall of the fungus. The inhibitory capability of the bacteria is also reinforced by Parvin et al. (2016) statement that $P$. aeruginosa isolated from the palm oil plant rhizosphere produces metabolite products such as phenazine in order to inhibit the growth of $G$. boninense.

\section{Acknowledgements}

This study was supported by Agency for Assessment and Application of Technology, Serpong, South Tangerang. We thank Ms. Rizdika Mardiana for helped in this manuscript.

\section{References}

Abdel-Raouf N, Ibraheem IBM. 2008. Antibiotic activity of two Anabaena species against four fish pathogenic Aeromonas species. Afr J Biotechnol 7:2644-2648.

Akhtar MS et al. 2010. Biocontrol of fusarium wilt by Bacillus pumilus, Pseudomonas alcaligenes, and Rhizobium sp. on lentil. J Biol 34:1-7.

Asaka O, Shoda M. 1996. Biocontrol of Rhizoctonia solani damping- off of tomato with Bacillus subtilis RB14. Appl Environ Microbiol 62:4081-4085.

Ausubel FM et al. 1997. Current Protocols in Molecular Biology. Hoboken: John Wiley and Sons.

Azizah SN et al. 2015. Potential of chitinolytic Bacillus amyloliquefaciens SAHA 12.07 and Serratia marcescens KAHN 15.12 as biocontrol agents of Ganoderma boninense. Res J Microbiol 10:452-465.

Bivi MR et al. 2010. Control of Ganoderma boninense: a causal agent of basal stem rot disease in oil palm with endophyte bacteria in vitro. Int J Agric Biol 12:833839.

Caldeira AT et al. 2007. Bacillus amyloliquefaciens CCMI 1051 in vitro activity against wood contaminant fungi. Annals Microbiol 57:29-33.

Chong KP et al. 2012. The role of syringic acid in the interaction between oil palm and Ganoderma boninense, the causal agent of basal stem rot. Plant Pathol 61:953-963.

Cui TB et al. 2012. Isolation and partial characterization of an antifungal protein produced by Bacillus licheniformis BS-3. Molecules 17:7336-7347.

Drancourt $\mathrm{M}$ et al. 2000. 16S ribosomal DNA sequence analysis of a large collection of environmental and clinical unidentifiable bacterial isolates. J Clin Microbiol 38:3623-3630.
Figueroa-Lopez AM et al. 2016. Rhizospheric bacteria of maize with potential for biocontrol of Fusarium verticillioides. Springer Plus 5:1-12.

Frank JA et al. 2008. Critical evaluation of two primers commonly used for amplification of bacterial $16 \mathrm{~S}$ rRNA genes. Appl Environ Microbiol 74:2461-2470.

Gomathi D et al. 2012. Secondary metabolite credential of Evolvulus alsinoides by high performance thin layer chromatography (HPTLC). J Biomed Res 26:295-302.

Gupta MK et al. 2012. Pharmacognostical evaluations of the leaves of Ziziphus mauritiana. Int J Pharm Sci Res 3:818-821.

Hadizadeh et al. 2009. Antifungal activity of essential oils from some medicinal plants of Iran against Alternaria alternate. J Appl Sci 6:857-861.

Indarti D et al. 2014. Outlook for Oil Palm Commodity. Jakarta: Ministry of Agriculture.

Johnson LF, Curl EA. 1972. Methods for Research on The Ecology of Soil-Borne Plant Pathogen. Minnesota: Burgess Publishing Co.

Laniado-Laborin R, Cabrales-Vargas MN. 2009. Amphotericin B: side effects and toxicity. Rev Iberoam Micol 26:223227.

McKane L, Kandel J. 1998. Microbiology: Essentials and Applications. Philadelphia: McGrow-Hill Inc.

Naher L et al. 2012. Activities of chitinase enzymes in the oil palm (Elaeis guineensis Jacq.) in interaction with pathogenic and non-pathogenic fungi. Plant Omics J 5:333-336.

Nawangsih AA et al. 2010. Selection and characterization of endophytic bacteria as biocontrol agents of tomato bacterial wilt disease. HAYATI J Biosci 18:66-70.

Parvin W et al. 2016. Detection of phenazines from UPMP3 strain of Pseudomonas aeruginosa and its antagonistic effects against Ganoderma boninense. Int J Agric Biol 8:483-488.

Petatan-Sagahon I et al. 2011. Isolation of bacteria with antifungal activity against the phytopathogenic fungi Stenocarpella maydis and Stenocarpella macrospora. Int J Mol Sci 12:5522-5537.

Prapagdee B et al. 2012. Efficacy of crude extract of antifungal compounds produced from Bacillus subtilis on prevention of anthracnose disease in Dendrobium Orchid. Environ Asia 5:32-38.

Ramachandran R et al. 2014. A broad-spectrum antimicrobial activity of Bacillus subtilis RLID 12.1. Sci World J 2014: 968487. DOI:10.1155/2014/968487

Ramli NR et al. 2016. The potential of endophytic bacteria as a biological control agent for Ganoderma disease in oil palm. Sains Malays 45:401-409.

Schultz D, Kishony R. 2013. Optimization and control in bacterial lag phase. Bio Med Cen Biol 11:1-3. DOI:10.1186/1741-7007-11-120

Suryadi Y et al. 2014. Characterization of bacterial isolates producing chitinase and glucanase for biocontrol of plant fungal pathogens. J Agric Technol 10:983-999.

Susanto A et al. 2005. Enhancing biological controlof basal stem rot disease (Ganoderma boninense) in oil palm plantations. Mycopat 159:153-157. 
Vater J et al. 2002. Matrix-assisted laser desorption ionization-time of flight mass spectrometry of lipopeptide biosurfactants in whole cells and culture filtrates of Bacillus subtilis C-1 isolated from petroleum sludge. Appl Environ Microbiol 68:62106219.

Wagner $\mathrm{H}$ et al. 1984. Plant Drug Analisis a Thin Layer Chromatography Atlas. New York : Berlin Heidelberg.
Zarei M et al. 2012 Chitinase isolated from water and soil bacteria in shrimp farming ponds. Iran J Fisher Sci 11:911-925.

Zvanych R et al. 2014. Small molecule immunomodulins from cultures of the human microbiome member Lactobacillus plantarum. J Antibiot 67:85-88. 